IwONA BORUSZKOWSKA

Uniwersytet Jagielloński*

(iD) https://orcid.org/0000-0001-8021-9210

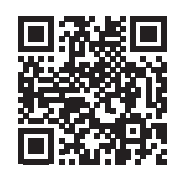

\title{
Paradoksy awangardowego zaangażowania. Ideologia (artystycznej) zmiany w powieści Palę Paryż Brunona Jasieńskiego
}

Paradoxes of the Avant-Garde Engagement. The Ideology of (Artistic) Change in Bruno Jasieński's I Burn Paris

\begin{abstract}
The article contains considerations about the political and ideological engagement of the avantgarde writer that were developing in the inter war period and which have their origins amongst, for example, avant-garde ideas. The paper analyses Bruno Jasieński's text "Palę Paryż" (I burn Paris) (1931), while the context for the novel is a critical revision of the relationship between politics and literature.
\end{abstract}


* Katedra Teorii Literatury Uniwersytetu Jagiellońskiego ul. Golębia 16,p. 41, 31-007 Kraków e-mail: iwona.boruszkowska@uj.edu.pl

Tekst powstał w ramach projektu Style zachowań awangardowych (program Sonata 10, nr rej. 2015/19/D/HS2/01003) finansowanego przez Narodowe Centrum Nauki. 
Rozpoznania i próby definicji złożonych zjawisk w binarnych opozycjach, pozornie porządkujące i odsłaniające sensy, prowadzić mogą do wykluczenia zjawisk niepoddających się upraszczającym klasyfikacjom. W przypadku awangardy — której próba usystematyzowania nader często zaczyna się od pustych stwierdzeń, jakoby było to zjawisko wymykające się opisom, trudne do zdefiniowania, płynne, zmienne, a przez to nieuchwytne — prowadzi do pominięcia całego spektrum najciekawszych może cech pośrednich awangardy, tych znajdujących się między wyrazistymi awersami i rewersami. Zwłaszcza w rozważaniu na temat rewolucyjności awangardy, czy nie najciekawsze jest właśnie to, co pomiędzy awangardą impasu a awangardą działania, awangardą zaangażowaną a awangardą apolityczną, awangardą rewolucjonizatorską a dialogującą z tradycją, ,elastyczną umysłowo” (Segovia 1978: 42), otwartą a ślepo realizującą założenia manifestów ją konstytuujących? Rola manifestów w przypadku nowej sztuki jest nie do przecenienia. Jorge Segovia traktuje je jako „rzucone beztrosko wyzwanie a priori” (Segovia 1978: 42). A sam awangardowy projekt rozpatrywać można jako rezultat procesu będącego próbą (w znaczeniu „laboratorium”) realizacji tych rzucanych na gorąco wyzwań "nowego” - wprowadzania radykalnie „nowego” elementu w pole sztuki (przez zanegowanie tego, co zastane) lub też jako radykalne praktyki tego wprowadzania (przez formułę eksperymentu). W ten sposób tworzy się kolejna opozycja: awangardowości jako eksperymentatorskiego rewolucjonizowania świata (sztuki) przeciwstawionego tradycyjnemu przedstawianiu przy pomocy zastałych artystycznych praktyk. W takim ujęciu awangarda to wymyślanie, praca wyobraźni, powoływanie do życia nowego, w czym kryłby się rewolucyjny potencjał. Przypisywane awangardzie nowatorstwo to także ustanowienie nowej zasady ontologicznej dzieła: opartej na formie zaprzeczenia, nie-użyteczności, nie-tradycyjności, nie-dokończenia, a w skrajnych przypadkach — nie-bytu. Elementem organizującym takie podejście do awangardy jest negacja. Zaprzeczenie może przybierać różnorodne formy, dotyczyć negacji słów, redukcji liter, wprowadzania pustej przestrzeni na karty utworu, ograniczenia elementów realistycznych, może być wierszem wolnym, poezją konkretną, uwalnianiem słowa, usamodzielnianiem metafory. Wszystko to bowiem są elementy rewolucji języka (a jak utrzymuje Segovia, za pomocą języka i słów dokonać można niezliczonych rewolucji): 
Uwolniona od patronatów, pozbawiona hamulców poezja zaczęła odnajdywać samą siebie, a poprzez to przybliżać się do realizacji swojej roli społecznej. [...] Głęboko sięgająca władza języka i jego swobodne zastosowanie uczyniły z poezji formę o wielkiej nośności poznawczej i szerokim zasięgu w świecie ekspresji. (Segovia 1978: 45)

Nie tylko poezja zaczyna pełnić nowe role, to przede wszystkim u twórców wyzwalają się rozszerzone możliwości tworzenia. Celem takiej ogólnej rewolucji artystycznej jest zapanowanie nad światem ekspresji, wyzwolenie go z konwencji i tradycji, artystyczne przeobrażenie, rozumiane jako rewolucyjne praktyki, bowiem „awangarda albo jest rewolucyjna, albo jej nie ma wcale" (Segovia 1978: 54). Szereg artystycznych deklaracji awangardzistów kształtuje postawę przychylną rewolucji totalnej (obejmującej każdy poziom działalności czy życia), której podstawowym celem jest transformacja, reorientacja, przeskok.

$\mathrm{Na}$ pytanie, jakiej rewolucji dokonuje awangarda, stara się odpowiedzieć Philippe Sers, pisząc, iż:

Rewolucje, które zapoczątkowała awangarda, grupują się wokół czterech głównych ruchów syntezujących: pierwszym jest walka prowadzona przez abstrakcję z figuratywnością w malarstwie, kierowana przez Kandinsky’ego, Pieta Mondriana i Kazimierza Malewicza; drugi to walka poezji z literaturą na polu twórczości werbalnej, wiedziona przez poetów zaumu oraz trans-rozumu, jak też przez dadaizm i surrealizm Bretona; trzecim będzie walka wymiaru wnętrza przeciwko stylowi w architekturze, której głównym teoretykami byli Theo van Doesburg oraz Le Corbusier; w końcu czwarty to walka teatru "metafizycznego” przeciwko dramatowi psychologicznemu w scenografii, dowodzona wielkimi głosami Hugo Balla i Antonina Artaud ${ }^{1}$. (Sers 2010: 854)

W jaki sposób dokonuje się rewolucja artystyczna w awangardowych kręgach? Przede wszystkim na polu manifestów, które służyć miały przekształcaniu świata: „manifest przybiera [...] formy władcze lub rewolucyjne, udrapowany w stylistykę wypowiedzi dyktatora bądź apelu uzurpatora, nawołującego do przejęcia władzy — stąd dekret [...], ukaz, gramota, agitka, odezwa, proklamacja czy orędzie" (Czapliński 1994: 11). Retoryczna funkcja rewolucyjnych haseł manifestów miała swój cel, a było nim przekonanie ogółu o konieczności czynu, zmiany, aktywnego działania i produktywności na różnych płaszczyznach. Już w 1908 roku Karol Irzykowski nawoływał do tego, aby poeci wyrażali swoje zaangażowanie, pisząc, że potrzeba właśnie takich ludzi pióra i myślicieli, którzy będą posługiwali się „hasłami polityczno-społecznej rewolucji” (Irzykowski 1908: 4). Deklarowana polityczność literatury w utopijnej myśli łączyła słowo i czyn, artystyczną i życiową praktykę, powodowała przenikanie się różnych warstw artystycznej i społecznej przestrzeni.

Retorykę rewolucji wychwycić można spomiędzy (i bezpośrednio z) wersów twórczości Brunona Jasieńskiego: jego wczesne poematy (ukazujące niezgodę na niesprawiedliwość społeczną i sprzeciw wobec niej - Pieśń o gtodzie czy będące opowieścią o rewolucji uciśnionych chłopów - Stowo o Jakubie Szeli) są demonstracją lewicujących poglądów i ideologii radykalnych przemian społecznych, z kolei teksty programowe i manifesty — awangardowych, nowatorskich poglądów na sztukę i ideologię artystycznej zmiany. Jest zatem polski futurysta poetą oddanym sprawie politycznej, socjalistycznej, artystą rewolucji, rewolucjonistą sztuki, którego radykalność i zaangażowanie obejmują różne pola działalności (treść, forma, życie).

1 Jeżeli nie zaznaczono inaczej — cytaty w thumaczeniu własnym - I.B. 
Sympatię Jasieńskiego do rewolucji uchwycił Anatol Stern, nazywając poetę „futurystą walczącym o nowy świat":

poezja nasza zrywała z tradycjami przeszłości, walczyła o nowy kształt życia i sztuki, dążyła do zdynamizowani świata. Z tym, że Marinetti, pragnąc przerwać śpiączkę swego narodu, głosił kult siły, futuryści polscy zaś, podobnie jak rosyjscy, głosili hasła buntu w imię sprawiedliwości społecznej.

(Stern 1969: 27)

Był Jasieński bezpośrednim uczestnikiem działań politycznych, agitował i uprawiał propagandę; mariaż z komunizmem łączył z wiarą, iż tworzy dzieła nowe. W każdym jego rewolucyjnym działaniu narzędziem był dla niego język pozwalający ukształtować nowe społeczeństwo, wyartykułować wizje nowego świata, wynaleźć nowe możliwości opisu, poszerzyć granice wyobraźni, czyli de facto osiągnąć cel zbieżny awangardy i polityki: dokonać zmiany na poziomie świadomości.

Swoje oddanie lewicowej ideologii i służbie literackiej na rzecz partii komunistycznej, o której pisał do samego Stalina² (Jaworski 1995: 94-97), przypłacił Jasieński życiem. Po publikacji powieści Pale Paryż z powodu działalności prokomunistycznej został zmuszony do opuszczenia terytorium Francji i wyjechał do ZSRR (30 kwietnia 1929 r.), gdzie po kilku latach został aresztowany przez NKWD i zamordowany podczas stalinowskich czystek (Jaworski 1995).

\section{Polityka a literatura - awangardowe zaangażowanie}

Ruch, ujęty w ramy formuły, jest już ruchem martwym, zaporą, którą trzeba przeskoczyć. Żywymi są ludzie, i to ci, którzy nie tworzą według swego manifestu [...]. Kto nigdy nie miał swojego manifestu, kto nic nie porzucał, nie ma nic w życiu do powiedzenia

- deklaruje Jasieński w tekście Futuryzm polski (bilans) (1972: 235) i jest to deklaracja eks-futurysty czy też post-futurysty, który przepracował już najbardziej charakterystyczne dla nurtu pojęcia, ale niekoniecznie je odrzucił. Przesłanie autora Palę Paryż zawiera w sobie deklarację aktywistycznej strategii opartej na gorzkiej konieczności negacji, odcięcia, porzucenia (idei, estetyki, poglądów). W tekstach Jasieńskiego manifestuje się postawa awangardowa będąca krytyczno-emancypacyjną, aktywną wobec rzeczywistości postawą podmiotu chcącego zmiany świata. Taki światopogląd koresponduje z romantyczną wizją twórcy (czy raczej z niej wypływa) jako prawodawcy nowych możliwości (poprzez manifesty, ale też swoją artystyczną i życiową praktykę), postrzegającego sztukę jako narzędzie zmiany myślenia, czucia, działania. Wynika to „z romantycznej wiary w szczególną społeczną rolę poety, czyniącą poetę i artystę zarówno prorokiem przyszłego świata, jak i rewolucjonistą" (Russell 2001: 166). W tej romantycznej gloryfikacji indywidualizmu u rewolucyjnego awangardzisty odnaleźć można ślady antagonizmu, o którym Charles Russell pisał: „dokonania awangardowego aktywizmu niosą z sobą świadectwo nierozwiązanego — i może nierozwiązywalnego — konfliktu między żądaniami estetycznej i wizjonerskiej wyobraźni a wymaganiami społecznej praxis" (Russell 2001: 166).

2 Zob. List Brunona Jasieńskiego do Józefa Stalina z 28 kwietnia 1937 r. 
John Roberts, zasadniczo nie zgadzając się z tezami Bürgera ${ }^{3}$ dotyczącymi rewolucyjności awangardy (jakoby niemożliwym czy destrukcyjnym dla sztuki był mariaż czynu i słowa), podkreśla, że:

nie istnieje konstruktywizm ani produktywizm bez rewolucyjnych przemian, wobec których były one odpowiedzią oraz których były produktem. W tym też sensie nie ma awangardy bez zmieniających świat transformacji rewolucji październikowej. To fakt: awangardy jako pewnego wyróżnialnego zestawu społecznych i kulturowych ideałów (raczej niż jako nazwy nadanej przez francuskich komentatorów z końca XIX wieku wszystkiemu, co artystycznie 'zaawansowane' w teorii), nie da się oddzielić od zrywu, jakim była rewolucja w Rosji. (Roberts 2010: 718)

Badacz przestrzega, że czynienie z awangardy nieudanego projektu społecznej rewolucji czy swoistej „idei klęski” powoduje zamykanie jej pod strażą czynników zewnętrznych, nieartystycznych, pozostających poza przestrzenią estetyki czy teorii. Awangardowe praktyki (określone przez artystyczne, społeczne czy polityczne wymogi rewolucji), mając potencjał emancypacyjny, wyprzedzały swój czas (czy to czas rewolucji październikowej czy każdy inny), czyniąc z nowej sztuki projekt otwarty, wymykający się projektowanej klęsce w przyszłość. Takie podejście pozwala badaczowi włączyć rewolucyjny potencjał do fundamentalnych cech awangardowości projektów artystycznych, ustanowić „rewolucyjną” tożsamość (nowej) sztuki, która wcale nie będzie odcinać się od przeszłości, ale będzie jej pełną potencjału przewrotną kontynuacją: „awangarda jest rewolucyjna właśnie na mocy swej wierności wobec własnych przesztych przysztości (future past)" (Roberts 2010: 720).

Relacja polityki i literatury leżała w horyzoncie zainteresowań zarówno awangardowych twórców, jak i późniejszych interpretatorów ich artystycznych poczynań. Wpływ ideologii, zaangażowanie w życie społeczne, polityczność dzieła czy rola twórcy - to tylko nieliczne z tematów, dla których nowa sztuka próbowała wynaleźć nowy język. I choć podporządkowanie artystycznej praxis celom politycznym widzieć można jako „trudne przymierze” (Lee 1982) czy „społeczną utopię” (Lipatow 1992), to popularności swoistego mariażu sztuki i polityki w polu awangardy nie da się zaprzeczyć. Kierunkiem szczególnie zideologizowanym, poddanym władzy haseł zawartych w manifestach, mającym ambicję przebudowy rzeczywistości był futuryzm. Oddani idei przebudowy świata artyści tego nurtu zacieśniali związki literatury z polityką, zwłaszcza z radykalnymi ideami lewicy.

Zaangażowanie zdaje się niezbywalnym elementem postawy twórcy (neo)awangardowego. W artystycznym i pozaartystycznym polu jego działalności naturalnymi i oczekiwanymi od niego gestami są podważanie zastanego porządku, kwestionowanie utartych schematów i krytyka aktualnych dróg myślenia; poszukiwanie nowego, wyrażanie swej indywidualności twórczej, idea przekształcania świata, zaangażowanie w jego przebudowę. Stefan Morawski przypisuje twórcy zaangażowanemu trzy funkcje, definiując go jako kogoś, kto „chce wyrazić siebie, swoje pasje i myśli”, „proponuje określony światopogląd artystyczny [...] w postaci [...] jakiegoś manifestu”, uważa wreszcie zaangażowanie za „określony sposób bycia, styl życiowy, działanie zarówno artystyczne, jak i poza instytucjonalnymi granicami sztuki” (Morawski 1978: 11). Te trzy sfery artystycznej i życiowej praxis nakładają się na siebie i przenikają wzajemnie. Bürger zaś upatruje zaangażowania awangardy w aktywnościach, takich jak „atak na

3 Bürger rozpatruje problem zaangażowania dzieł sztuki awangardowej: niepowodzenie historycznych nurtów awangardowych utożsamiających sztukę z praktyką życiową. 
status sztuki w społeczeństwie mieszczańskim" (Bürger 2006: 61) - i to zarówno w formie społecznego aktywnego sprzeciwu, jak i we wszelkich formach eksperymentowania.

Laboratorium rewolucji awangardowej były nie tylko dzieła czy manifesty, forma czy język, ale także zwykła rzeczywistość pozaliteracka, w której twórcy angażowali się w działalność mającą na celu prawdziwą zmianę zastanego porządku, nader często podpisując się pod hasłami lewicy: „padały słowa ciężkie, obtłuczone jak brukowce: rewolucja, proletariat, kapitalizm” (Jasieński 1974: 36). Jasieński zdaje się pisarzem idealnym do omówienia problemu artystycznego zaangażowania czy wyszukiwania w tekście śladów koncepcji politycznych czyniono tak zresztą niejednokrotnie. Można też potraktować twórczość tego niewątpliwie ulegającego ideologii autora nie tylko jako dzieło zaangażowane w służbę lewicowym hasłom, ale też jako świadectwo tekstowego zaangażowania w ideę estetyczną, etapy obmyślania założeń futuryzmu (czy raczej etap ostatni: likwidatorski, rozliczeniowy), odpowiedź na zastaną rzeczywistość i ówczesną literaturę - które to wymagały przebudowy.

\section{Bruno - pisarz-komunista: "poprowadzę was wszystkich w czerwonych pląsach" 4}

W twórczości Jasieńskiego dochodzą do głosu lewicowe przekonania, czyni on bohaterami swoich utworów robotników, przedstawia burżuazyjny wyzysk i niedole proletariatu. Próbuje też w mocno utopijnych (czy wręcz dystopijnych) wizjach nakreślić nowy światowy ład, który nastanie po rewolucji (proletariackiej). W latach 1927-28 publikuje w „Dźwigni” wiersze (Zaktadnicy, Do proletariatu francuskiego) będące „orężem komunisty-agitatora przemawiającego do proletariatu” (Rawiński 1971: 95). Praktyka artystyczna zaczyna być sprzężona z jego działalnością w sekcji polskiej Komunistycznej Partii Francji (głównie oświatowo-agitacyjną). O zaangażowaniu Jasieńskiego w idee rewolucji świadczą wymienione przez Sterna działania poety: „redaktor pisma polskiego «Kultura Mas» i pisma międzynarodówki komunistycznej wydawanego w Moskwie w języku francuskim pt. «La Littérature de la Revolution Social». [...] Namiętność polityczna spalała go jak pożar” (Stern 1969: 139). Zaś sam poeta otwarcie deklarowat:

Jako pisarz proletariacki, za jakiego mam się zaszczyt uważać, solidaryzuję się całkowicie, pomimo pewnych dzielących nas różnic wyrazu formalnego, z tymi nielicznymi w Polsce, którzy swe rzemiosło poetyckie obrócili w oręż walki o nowe formy życia zbiorowego, wykuwane przez polską klasę robotniczą. (Jasieński 1928, cyt. za: Jaworski 2009: 163)

Czas spędzony w Paryżu był dla autora okresem głębokiego zaangażowania w działalność ruchu komunistycznego: jako członek Francuskiej Partii Komunistycznej agitował i organizował różne inicjatywy (np. teatr robotniczy). Również na papierze — w słanej do „Kuriera Lwowskiego” czy „Wieku Nowego” korespondencji bądź w utworach pisanych w stolicy Francji (Stowo o Jakubie Szeli, Palę Paryż) — przemycał apoteozę rewolucji.

4 B. Jasieński, Psalm powojenny, za: Jasieński, Stern 1987: 14.

5 Inne utwory Jasieńskiego mówiące o zaangażowaniu w sprawy społeczno-polityczne to m.in. wiersze: $D o W$. Pana Jezusa, Śmierć Pana Premiera. Rapsod, Śpiew maszynistów; wiersze z „Ziemi na lewo” (1924): Bajka o kelnerze, Marsylianka, Psalm powojenny; wiersze z czasopism: Morse (pierwodruk w „Almanachu Nowej Sztuki” 1925, nr 2), Zaktadnicy (pierwodruk w „Dźwigni” 1927, nr 5), ZemBy. Rapsodia (pierwodruk w „Formistach” 1921, nr 5) czy wspominane już poematy Pieśn o gtodzie i Stowo o Jakubie Szeli. 


\section{Pale Paryż - apokaliptyczna agitka}

Jasieński przebywał w stolicy Francji od 1925 r. do 1929 r., kiedy to z powodu publikacji kontrowersyjnej powieści, w której metropolia zostaje skazana na zniszczenie, zostaje wydalony z kraju (Jaworski 2003):

Francuska wersja Palę Paryż zapewniła Jasieńskiemu rozgłos i była przyczyną wydalenia autora z Francji. Stało się to 30 kwietnia 1929 roku. 22 maja Jasieński przyjechał do Moskwy, gdzie od razu przyjął stanowisko redaktora naczelnego „Kultury Mas”, polskiego miesięcznika literackiego wydawanego w Moskwie przez sekcję polską Wszechzwiązkowego Zjednoczenia Zrzeszeń Pisarzy Proletariackich, której sekretarzem był Tomasz Dąbal. (Kato 2018: 472)

Przez tych kilka lat miał okazję przyjrzeć się życiu miasta, odmalowując je też w drukowanych w „Wieku Nowym” listach (Dziarnowska 1978: 125-138), zaś w powieści Palę Paryż stworzył literacki portret miasta czasów zarazy. Już w wyborze tytułu utworu badacze dopatrują się politycznego gestu - Palę Paryż miało być bowiem odpowiedzią na antyradziecką nowelę Paula Moranda Pale Moskwę . Powieść polskiego autora ukazała się również w nieprzypadkowym miejscu: w kwietniu 1928 roku w Moskwie ukazało się jej rosyjskie wydanie, zaś we wrześniu tegoż roku ${ }^{7}$ utwór drukowano w odcinkach w komunistycznym czasopiśmie „L'Hummanité” i okrzyknięto politycznym skandalem (polskie wydanie miało miejsce w lipcu 1929 roku, a powieść wydrukowało wydawnictwo Rój; Jaworski 2009) ${ }^{8}$. Pisząc o polskiej literaturze proletariackiej, Józef Łobodowski określił powieść Jasieńskiego jako „nie tylko frapującą lekturę agitacyjną, ale również jedną z najlepszych polskich powieści” (Łobodowski 1932). Skąd zatem kontrowersje wokół publikacji? Utwór komentowano jako powieść, będącą głosem w politycznej debacie o literaturze proletariackiej czy społecznej, twórczości zaangażowanej, podporządkowanej ideologii. Późniejsi krytycy wskazywali na utopijność myśli Jasieńskiego i niebezpieczeństwa płynące ze strategii artystycznej podporządkowanej przebudowie świata według haseł socjalizmu (Mitzner 1993; Jaworski 2002).

\section{Katastrofizm bis}

Powieść Jasieńskiego osadzić można w nurcie katastrofizmu charakterystycznym dla czasów, w których powstawała. Awangardowy pesymizm, wynikający z przeżytych i przeczuwanych traum ${ }^{9}$ pierwszych dziesięcioleci XX wieku, zawładnął wyobraźnią także innych autorów, wśród których wskazać można Witkacego z jego powieściami (choćby Nienasycenie czy Pożegnanie jesieni), Romana Jaworskiego i jego Wesele hrabiego Orgaza (1925), Aleksandra Wata z cyklem Bezrobotny Lucyfer, Jalu Kurka i jego powieści S.O.S. (Zbaw nasze dusze) i Kim byt Andrzej Panik, czy choćby Anatola Sterna z poematem Europa. Mimo deklarowanego przez futurystów optymizmu cywilizacyjnego czołowy polski przedstawiciel tego nurtu nie unikat

6 Polemiki na temat inspiracji powieścią Moranda i genezy tytułu Palę Paryż zebrał i opisał we wstępie do jednego z wydań powieści Piotr Kitrasiewicz (2005).

7 Dokładnie od 14 września 1928 do 13 listopada $1928 \mathrm{r}$.

8 Powieść Je brûle Paris (Palę Paryż) opublikowana została w 1928 roku w Rosji w moskiewskim dwumiesięczniku literackim „Роман-газета” („Roman-gazeta”) i w odcinkach na łamach francuskiego czasopisma „L'Humanité", zaś rok później z przedmową Kadena-Bandrowskiego w Polsce (wydana przez Rój).

9 Wzmacnianych przez literacką, artystyczną czy filozoficzną refleksję na temat końca, kresu, zmierzchu (Zmierzch Zachodu Oswalda Spenglera, Upadek cywilizacji zachodniej Floriana Znanieckiego czy inne), charakterystyczną dla modernistycznego dekadentyzmu. 
gatunku powieści katastroficznej, czy wręcz apokaliptycznej, jak nazwał ją Szymański (1929: $37)^{10}$. Jednak schyłkowe nastroje ukazane w Palę Paryż związane są ściśle z sytuacją społeczno-polityczną, nie zaś z przeczuwanym końcem świata czy powszechnie panującym kryzysem. Ponadto wymienione utwory innych polskich autorów wydają się prezentować katastrofę w stylu buffo, zaś powieść Jasieńskiego nie zdradza pociągu do groteski, parodii czy drwiny (Rawiński 1971), tworząc obraz raczej utopijny. Wspólne dla zespołu katastroficznych motywów są w powieści „nieuchronność zagłady i związane z nią symptomy dezintegracji społecznej, wynaturzenie kultury i cywilizacji, rewolta zbuntowanej masy" (Bujnicki 1993: 177). Na tych planach zakwestionował Jasieński zarówno status francuskiej metropolii jako centrum świata kultury, jak i kapitalizmu jako najlepszego ekonomicznego systemu, a także ukazał dezintegrację demokracji, rodzącej jedynie podziały i konflikty społeczne, zaś mieszczańską formację kulturową — jako archaiczną. W wizji idealizującej system socjalistycznej organizacji społeczno-politycznej autor dokonuje zagłady jedynie wybranych elementów rzeczywistości, na gruzach których powstaje nowy komunistyczny ład, a całość kończy się wezwaniem do powszechnej światowej komunistycznej rewolucji.

W recenzji Andrzeja Stawara z 1929 roku (rok ukazania się powieści w wydawnictwie Rój) pada wspomniane już sformułowanie: „Zamierzona była ponoć powieść rewolucyjna, wyszła zaś z warsztatu literackiego powieść apokaliptyczna” (Szymański 1929: 37). I faktycznie, programowy radykalizm w warstwie języka nie zbliża się do wzorców literatury socjalistycznej mimo obrania w trzecim rozdziale konwencji prozy reportażowej eks-futurysta naraził się na krytykę pisarzy lewicowych i nie tylko ${ }^{11}$ (Balcerzan 1968: 326, 321-328; Kolesnikoff 1982).

\section{Pale Paryż}

Jak słusznie zauważa jeden z interpretatorów twórczości prozatorskiej Jasieńskiego, Tadeusz Bujnicki, trzy części powieści Palę Paryż utrzymane są w różnych konwencjach: powieści brukowej, symultanicznych nowel, prozy reportażowej (Bujnicki 1984: 180-185), różni je poruszana tematyka i obrane przez autora rozwiązania formalne. Niezależnie jednak od wybranej konwencji powieść jest topograficznie realistyczna i stanowić mogłaby swoisty bedeker Paryża lat dwudziestych (na kartach powieści padają nazwy ulic, budowli, świątyń, kawiarni, zaułków, charakterystycznych punktów jak Pola Elizejskie czy Łuk Triumfalny, a nawet całych dzielnic). Na pytanie, dlaczego autor tak szczegółowo odmalowuje literacki portret Paryża, odpowiada badacz twórczości Jasieńskiego:

Dla miasta, które ma być zniszczone, prawdopodobieństwo topograficzne musiało być posunięte do maksimum. [...] Szczegół miał tu za zadanie potęgować zagrożenie tak, by przemierzając Paryż, niemal czuć wiszącą w powietrzu apokalipsę, tragedię, która rozegra się tu i teraz, na oczach współczesnych, w konkretnym miejscu i czasie. (Jaworski 2002: 103, podkr. autora)

10 Powieścią społeczno-fantastyczną określa Palę Paryż Anatol Stern (1969: 141), zaś inni — jak na przykład Bujnicki — antykapitalistyczną (Bujnicki 1993: 173).

11 Ponieważ istnieje wiele różnych wydań i wersji powieści, Palę Paryż sprawia niemały kłopot interpretatorom: zastanawiać się można, który wariant jest ostateczny (jeżeli takie stanowisko w ogóle można uzgodnić). W Rosji ukazały się wersje powieści z zupełnie innym zakończeniem, jak podkreśla Edward Balcerzan (1968: 325) — były to wersje dopasowane do wymogów realizmu socjalistycznego. 
Fabuła powieści nie wydaje się nader skomplikowana — w pierwszej części biedny robotnik Pierre traci pracę, przychylność dziewczyny Jeanette i dach nad głową, a wydaje się też, że z powodu nękającego go głodu - i zmysły. Upokorzenie, wyczerpanie oraz głód powodują osuwanie się bohatera w delirium, doprowadzają go na skraj psychicznej i fizycznej wytrzymałości, powodują szaleństwo, egzystencję na granicy jawy i snu („poza granicą trójwymiarowej rzeczywistości”; Jasieński 1974: 34), a przynajmniej zaburzenia i deformacje rzeczywistości („świat załamujący się w obłąkanej wyobraźni bohatera jest [...] odbiciem zdeformowanej struktury kapitalistycznej rzeczywistości i jej absurdu”; Bujnicki 1984: 182). Burżuazyjna, kapitalistyczna metropolia jawi się biednemu robotnikowi jako potwór. Opozycja burżuazyjnego przesytu i socjalistycznego niedosytu prowadzić może wyłącznie do upadku, do zniszczenia, do rewolucji. Nie jest to oczywiście jedyne możliwe odczytanie — odrealnienia opisu i zniekształcenia rzeczywistości można uznać za surrealne eksperymenty prozatorskie.

Główny bohater pierwszego rozdziału błąka się po paryskich ulicach, trafia do więzienia, aż w kluczowym punkcie ratuje go kolega z lat młodości - René, który zabiera bezdomnego do siebie. Los się odwrócił — Pierre dostaje pracę w „wieży ciśnień na stacji filtrów miejskich w Saint-Maur" (Jasieński 1974: 45). Jednak upokorzenie nie mija i bohater postanawia w akcie zemsty zatruć Paryż zarazkami dżumy hodowanej w laboratorium, w którym pracuje jego przyjaciel, i wysłać zarazę w „wygłodniałe arterie dalekiego, śpiącego Paryża” (Jasieński 1974: 52).

Pozostałe wątki części drugiej są ze sobą luźno powiązane, niejako odseparowane od siebie - niemal jak niezależne państewka utworzone na terenie Paryża w trakcie epidemii dżumy, do której doprowadził desperacki gest Pierre’a. W centralnym rozdziale powieści splatają się wątki skupione wokół postaci: chińskiego komunisty P’ana Tsiang-Kueia (wcielenie dojrzałego ideologicznie rewolucjonisty), rabina gminy żydowskiej Eleazara ben Cwiego (stereotyp przedstawiciela narodu wybranego), Rosjanina białogwardzisty — rotmistrza Sołomina (uosobienie okrucieństwa i anachronizmu politycznej emigracji), amerykańskiego miliardera Dawida Lingslaya (symbol kapitału rządzącego światem), towarzysza komunisty, kapitana Czerwonej Gwardii - Jacquesa Lavala (ideał romantycznego rewolucjonisty ginącego za swoje przekonania). Każdy z nich w jakiś sposób przedostaje się do Paryża i podczas epidemii pełni rolę przywódcy jednego z separatystycznych państewek, które powstają na terenie miasta. Zbiorowiska konstytuują się w niezależne parapaństwowe organizmy przedzielone kordonami i różnorodne pod względem ustroju, narodowości czy religii. Powstają republika „żółtych”, gmina żydowska, anglo-amerykański „trust” najbogatszych, republika radziecka, rosyjska monarchia, odrestaurowana monarchia Burbonów i zorganizowane w części trzeciej państwo więźniów proletariackich. Na czele pierwszej z wymienionych republik staje P’an, który działa w szeregach partii komunistycznej w Nankinie i jako tajny jej agent zostaje oddelegowany do Europy, aby szerzyć rewolucję chińską. Narrator poświęca mu zdecydowanie najwięcej uwagi, szczegółowo rekonstruując jego dzieciństwo i dojrzewanie ideologiczne. Jest uświadomionym politycznie i ideowo wyznawcą marksizmu i zdecydowanie najszerzej prezentuje swoje poglądy na temat rewolucji chińskiej i ruchów antykolonialnych w Azji. W rozmowie z profesorem Sorbony deklaruje:

Wasza nauka, z której jesteście tacy dumni i którą przyjeżdżamy do was studiować, nie jest systemem narzędzi panowania człowieka nad przyrodą, lecz systemem narzędzi panowania Europy nad nie-Europą, systemem narzędzi wyzysku słabych kontynentów. [...] To my, sadzący ryż, hodujący bawełnę i herbatę, jesteśmy na równi z waszym własnym proletariatem właściwymi, chociaż pośrednimi twórcami waszej kultury. (Jasieński 1974: 119) 
Z każdą z naszkicowanych mniej lub bardziej schematycznie czy stereotypowo postaci i z każdym z powstałych na terenie zadżumionego Paryża państewek wiąże się funkcjonujący w latach dwudziestych XX wieku w Europie mit, z którym Jasieński zdaje się rozprawiać: mit o „żółtym niebezpieczeństwie” wielkiej chińskiej armii idącej na Europę, mit o syjonistycznym spisku, mit o wszechpotędze bajecznego amerykańskiego kapitału, o widmie komunizmu krążącego nad Europą i czerwonym niebezpieczeństwie bolszewizmu (Rawiński 1971).

\section{Bakcyl nowoczesności: miasto, masa, maszyna}

Bohaterem nowej idei postępu jest robotnik Pierre, nie wciela się on w rolę budowniczego, lecz staje się niszczycielem. Jego projekt jest projektem obliczonym na odwet, zemstę, katastrofę, walkę z bakcylem (rozumianym na różne sposoby). Dla futurystycznego „spektaklu postępu” (określenie Tadeusza Peipera ${ }^{12}$ ) Jasieński pisze scenariusz katastroficzny: buntu, rewolucji, zagłady. Nie jest w tych rozpoznaniach odosobniony, bowiem do pesymistycznych wniosków na temat nowoczesności dochodzą także inni awangardziści, odrzucając optymizm konstruktywizmu.

Miasto nie jest już areną futurystycznej fascynacji, staje się miejscem zupełnie nieprzyjaznym, przestrzenią zagrożenia, kupczenia ideami i ciałem. Nakreślony urbanistyczny obraz Paryża jest całkowicie pejoratywny, miasto to urasta do symbolu zła. Nie jest już wielkim nienapisanym poematem (jak u Jalu Kurka), z ducha urbanizmu uleciał zachwyt metropolią. Paryż zmienia się w obszar narastającego konfliktu społecznego, który prowadzi najpierw do epidemii, potem do rewolucji; obszar, w którym optymistyczny urbanizm nie jest już możliwy.

„Bezdusznie milczący”, „wielooki” Paryż jest miastem potwornym, krzykliwym, okrutnym i przerażającym, pełnym „ołowianostopych ludzi pod ciężkimi skafandrami parasoli” (Jasieński 1974: 14):

Szerokim wąwozem łożyska, z szumem elastycznych łusek opon płynęły stłoczone stada dziwacznych żelaznych ryb o ognistych, wybałuszonych ślepiach, ocierając się o siebie pożądliwie bokami w obłokach błękitnawej ikry benzyny. [...] Z dołu biło gęste, rozleniwiające ciepło rozgrzanych trzewi miasta, trawiących na czczo pierwsze porcje lekkich porannych pociągów. (Jasieński 1974: 14, 18)

Obcość miasta, jaka przebija z tych fragmentów, potęguje osamotnienie człowieka. Okrutny Paryż jest też miejscem ostrych podziałów klasowych — wielka przepaść dzieli „zarośniętych, obdartych ludzi”, którzy pozostają bezdomni na pełnych „ryczących automobili” ulicach miasta, oraz „opasłych galantów” i ich towarzyszki z wystawnych bankietów, przedstawicieli zamożnej burżuazji i arystokracji; bezdomnych i właścicieli wystawnych domów; głodnych i nasyconych; bezrobotnych robotników i bezdusznych kapitalistów — by wymienić tylko kilka odmalowanych przez poetę kontrastów społecznych.

Zdaje się, że robotnik Pierre, przedstawiciel ciemiężonego i wykorzystywanego proletariatu, to człowiek pochłaniany przez tłum, niezdolny do ocalenia swojej indywidualności, w którym budzi się resentyment: „W głębi bezczynnej świadomości [...] przypominała o sobie poczuciem nieusprawiedliwionej próżni głęboka, czarna jak szyb, nie zasklepiona rana” (Jasieński 1974: 46).

12 Peiper 1930: 8. 
Bohater zbiorowy w postaci burżuazyjnej masy doświadcza kryzysu swojej formacji, o którym pisał, diagnozując zmierz cywilizacji, Oswald Spengler, wskazując na kosmopolityzm, tanie rozrywki, płytką duchowość, którą Jasieński sugestywnie portretuje w opisie:

dostrzegł już tylko migot niezliczonych hotelików, mrowie nalanych krwią, opasłych karków i tysiąc kobiecych profilów, identycznych jak odbitki jednej i tej samej, tak dobrze pamiętanej twarzy. Ze wszystkich bram, przytulone do swych apoplektycznych gachów, wychodziły i wchodziły w gorączkowym pośpiechu dziesiątki i setki Żanet, jedna łudząco podobna do drugiej. (Jasieński 1974: 50)

O ile w Nogach Izoldy Morgan maszyny były głównym zagrożeniem, które inżynier Berg chciał zniszczyć, by nie dopuścić do zagłady świata, o tyle w Palę Paryż to ludzie stają się wrogami, których robotnik Pierre chce unicestwić. Jednak i w drugiej powieści osiągnięcia techniki ingerują w życie człowieka (Lubelski 1973): mechanizacja okazuje się niebezpiecznym wytworem cywilizacji. Obie powieści można za Aleksandrem Wójtowiczem określić powieściami o cieniu modernizacji. Badacz zauważa bowiem: „to alegoryczna opowieść o tym, w jaki sposób modernizacja wytwarza swój cień, wywołując postawy katastroficzne, oparte na przekonaniu, że rewersem rozwoju techniki jest dehumanizacja przestrzeni, w jakiej żyje człowiek" (Wójtowicz 2010: 253). Jasieński tworzy w powieści obraz świata-maszyny, który w warstwie dosłownej odsyła do futurystycznej obsesji, zaś w głębszym, metaforycznym znaczeniu - konieczności przebudowy starego porządku, nowej konstrukcji idei, stworzenia zupełnie innej maszynerii społeczno-politycznej:

Świat, jak źle skonstruowana maszyna, więcej niszczy, niż produkuje. Tak dalej niepodobna. Trzeba rozebrać wszystko aż do śrubek, co nieużyteczne - odrzucić, rozebrawszy zmontować na nowo, na fest! Plany leżą gotowe, monterów świerzbią ręce, tylko stare, zardzewiałe żelastwo nie puszcza. Wrosło, powrastało się w szwach tkanką rdzy — każdy gwint wypadnie odrywać zębami. (Jasieński 1974: 37)

Fetysz futurystów przeobraził się w źródło lęków nowoczesnego człowieka - wszechmoc i wszechobecność mechanizacji zrodziły poczucie zagrożenia spowodowane niekontrolowanym rozwojem cywilizacji, w której maszyna jest symbolem „destruktywnego i upokarzającego fizykalizmu nowoczesności” (Olsen 2013: 149). Rozwój techniki, przemysłu (oznaki nowoczesności) i wzrost znaczenia maszyny powodowały zmiany w psychice ludzi, miały także wpływ na modyfikacje estetyki i tematyki dzieł artystycznych. W innym tekście autor używa bardzo obrazowego porównania, nazywając futurystyczne uwielbienie maszyn „bakcylem nowoczesności” (Jasieński 1972: 237). Inaczej zatem niż Marinetti ${ }^{13}$ czy rosyjscy futuryści (Władimir Majakowski, Dawid Burluk) pojmuje polski pisarz założenia futuryzmu — „przez pojęcie futuryzmu [...] rozumiał [...] pewien stan świadomości, który odpowiada procesowi przezwyciężenia maszyny” (Stępień 1974: 13). Co prawda, Jasieński nie odrzucił maszyny jako elementu nowej estetyki, ale odsłonił jej niebezpieczeństwo, ukazał negatywną rolę, wzniecił lęki: „Olbrzymie maszyny, podobne do potwornych dwugłowych smoków, łykały szare kłęby pakuł, brudne jak dym, aby za chwilę wypluć je ciągliwą śliną długich włókien”

13 Włoscy futuryści głosili afirmację wytworów techniki. A w identyfikacji człowieka z maszyną i w koncepcji człowieka zwielokrotnionego (uomo moltiplicato) widzieli możliwość stworzenia nowego antropologicznego wzorca. 
(Jasieński 1974: 96). Opiewane przez futurystów zdobycze technologii ujawniają swoje złowrogie oblicze, okazują się siłą destrukcyjną, zagrażają nie tylko pojedynczemu ludzkiemu istnieniu, ale egzystencji całych społeczeństw.

\section{Zbuntowany bakcyl rewolucji}

Za symbol katastrofy obrał autor dżumę, ogromnie metaforyczną chorobę, wykorzystywaną w utworach pisarzy, których światopogląd zdawał się bliski Jasieńskiemu i egzystencjalistom (choć nieco później, jak Dżuma Alberta Camusa opublikowana w 1947 r.), związaną z wizjami, złem, samotnością, wyobcowaniem... Średniowieczna, obrosła znaczeniami zaraza staje się przyczyną zagłady miasta-symbolu, stolicy zachodniej Europy, centrum kapitalistycznego świata. Wykorzystanie obrazu choroby zbliża do retoryki katastroficznej w ujęciu (biblijno-)apokaliptycznym - choroba może być bowiem karą za grzechy burżuazyjnego społeczeństwa, za wyzysk i krzywdzące podziały społeczne. Trawiące burżuazyjne społeczeństwo symptomy rozkładu (wyzysk, korupcja, niesprawiedliwość...) zapowiadają nieuchronny koniec w postaci epidemii: „Paryż jak roztwór, do którego ktoś wlał silny odczynnik, rozkładał się w oczach na odrębne składniki” (Jasieński 1974: 155).

Wieńczącą kryzys katastrofą okazuje się zaraza, na kartach powieści dokonuje się swoista apokalipsa: „kapitalistyczny Babilon” zostaje ukarany, a sprawiedliwość wymierza jeden z uciśnionych. Jak się okazuje w trzeciej części powieści, jedynymi ocalałymi, wybranymi przez los, których dżuma oszczędziła, są proletariaccy więźniowie, odizolowani od ogniska choroby grubymi więziennymi murami, którzy wydostają się na ulice miasta, niedługo po tym, jak „skonsumowawszy ostatniego paryżanina, dżuma opuściła Paryż równie nagle, jak się w nim zjawiła” (Jasieński 1974: 178). Dżuma niczym narzędzie w rękach sił wyższych oszczędza prawych, każe zaś zgniły kapitalistyczny Zachód, pełniąc w utworze role ideowe, moralne i polityczne (prócz artystycznych oczywiście):

jej ingerencja w naszym odwiecznym sporze była najzupełniej zbyteczna. Absurdalność tej interwencji byłaby w stanie przekonać mnie o istnieniu waszego boga, którego triki, jeśli wierzyć autorom Pisma świętego, nie grzeszyły zbytnią inteligencją. Lata waszej imperialistycznej Europy były już tak czy inaczej policzone i nie było potrzeby przyśpieszać jej końca podobnym wybrykiem. (Jasieński 1974: 211)

Bohater wierzy, że nawet bez epidemii konflikty klasowe (które dżuma tylko wyostrzyła) doprowadziłyby do ogólnej rewolucji, zatem choroba spełnia konkretną historiozoficzną rolę, choć raczej jako element irracjonalny: jest przypadkowa. Służy jednak autorowi jako „instrument dogłębnej i wielostronnej [...] analizy imperializmu lat dwudziestych” (Rawiński 1971: 119) i współtowarzyszy rewolucji — umożliwia zaprowadzenie nowego porządku w zdziesiątkowanej przez siebie metropolii, a z serca Zachodu — na całym świecie, jak zapowiadają więźniowie w komunikacie: „metropolię świata zmienić na olbrzymie miasto komunistyczne, ognisko i komórkę, z której ustrój nasz rozpromieniuje na cały kontynent” (Jasieński 1974: 189).

\section{Anarchistyczne akty i konieczność rewolucji}

Gestem rewolucyjnym jest „podpalenie” Paryża — symbolu kulturowego mitu Zachodu, zepsucia burżuazyjnej zbiorowości, która według narratora nie wytworzyła żadnych wartościowych modeli społecznego współbycia ani użytecznych dla ogółu wartości, a której 
sztandarowe idee kończą, jak w poniższym fragmencie: „na frontonie więzienia girlandą spełzłych liter kokietował przechodniów poczerniały napis: «Wolność - Równość - Braterstwo», jak wypłowiała żałobna wstęga na zapuszczonej mogile Wielkiej Rewolucji Francuskiej" (Jasieński 1974: 37). Metropolia pozbawiona wyższych wartości budzi odrazę, opisywana jest za pomocą metafory domów publicznych, dancingów, prostytucji. Paryż nie zostaje podpalony w sposób dosłowny, autor dokonuje innego anarchistycznego aktu: zdehumanizowana zachodnia cywilizacja zostaje zniszczona za pomocą ognia symbolicznego bakcyla dżumy, który wypala miejsce na nowe wartości i idee.

Jasieński zrealizował w ten przewrotny sposób postulat Marinettiego, który w Akcie zatożycielskim i manifeście futuryzmu nawolywał do wyrazistego przeciwstawiania się kulturze przeszłości i jej symbolom. A stolica Francji takim symbolem również była, mało tego, była miejscem symbolicznym dla kwestionowanego przez Jasieńskiego nurtu futurystycznego to tam bowiem ogłaszał włoski przywódca ruchu swoje hasła, tam tworzyli futuryści różnych narodowości, to miasto uznano za centrum artystycznego świata i starego porządku:

W powieści Jasieńskiego zbiegły się dwie tendencje destrukcyjne: autodestrukcja futurystyczna oraz — implikowana polityczną ideą — zagłada symbolu świata kapitalistycznego. Młodzieńcze doświadczenie strategii skandalu przerodziło się w świadomą postawę artystycznego i ideologicznego buntu. (Majerski 2001: 73)

Pierre, romantyczny samotny rewolucjonista, który raczej jest destruktorem niż prawodawcą nowego porządku, ucieka się do jedynej możliwości, jaka pozostaje: do radykalnego gestu, obrachunkowego działania (z przeszłością, z futuryzmem, z kapitalizmem).

\section{Retoryka lewicowego zaangażowania — język i krytyczna rewizja futuryzmu}

Edward Balcerzan zwraca uwagę na językowe powinowactwo powieści i utworów poetyckich autora Pale Paryż, stawiając tezę, że jego twórczość można rozpatrywać jako swoistą liryczno-prozatorską transpozycję (Balcerzan 1968). Przenoszone przekształcenia dotyczą nie tylko języka czy metaforyki poezji i prozy, ale także stosunku do samej praktyki artystycznej (pożegnanie $\mathrm{z}$ futuryzmem deklarowane $\mathrm{w}$ tekstach programowych znalazło realizację $\mathrm{w}$ postaci utworów prozatorskich) czy krytycznej rewizji hasel futuryzmu.

W ostatniej części utworu pozostają jedynie: zasiedlona przez więzionych wcześniej proletariuszy republika paryska i Związek Radziecki - dwa rodzaje komunistycznych państw. Dominujące elementy w trzecim rozdziale to bohater pod postacią uświadomionej już zbiorowości oraz rewolucyjna czy partyjna retoryka, a wątek politycznego zaangażowania przenika tu do warstwy językowej. Najpełniejszy wyraz uzyskuje w części trzeciej w momencie, kiedy obwieszczona zostaje rewolucja. Hasła wzywające do powstania przybierają postać zakłócanego komunikatu:

Robotnicy! Żołnierze! Chłopi! Mówi do was rewolucyjny rząd Paryża. [...] Wszyscy do broni! Wszyscy na stronę rewolucyjnego Paryża! O niez... pok... z Związ... [...] - ...żyje ...twoja rewolucja robot... ...nierzy i chłopów! Precz z woj.... listyczną... żyje ...na domowa! Niech żyje Paryż, stolica Francuskiej Socjalistycznej Republiki Rad! (Jasieński 1974: 294-295)

Powieść Palę Paryż posiada wymowę rewolucyjną jeszcze z innego powodu — wybierając prozatorską formę utworu, odrzucił autor poezję, zrezygnował z niej na rzecz powieści jako formy bardziej komunikatywnej (Stern 1969: 144). Wymagała tego postawa zaangażowana: 
Coraz ostrzej uwidaczniająca się potrzeba wzięcia aktywnego udziału w rozpalającej się wokoło walce, środkami nie do odparcia zmusiła mnie porzucić wiersze i wziąć się do prozy. Rezultatem pracy był pierwszy mój utwór prozatorski, powieść Palę Paryż. (Jasieński 1956: 46)

Nie mogąc zupełnie zrezygnować ze swej roli artysty rewolucji, Jasieński porzuca jedynie lirykę z konieczności aktywnego zaangażowania w rozgrywającą się wokół walkę. Była to decyzja, która powodowała konieczność przyjęcia nowej roli - pisarza zaangażowanego, tworzącego na użytek proklamowanych haseł, sympatyzującego z ideami rewolucji proletariackiej. Autor Pieśni o gtodzie wierzył bowiem, że jako twórca służyć może społeczeństwu proletariackiemu i zaprowadzać nowy ład: „nowy ład zrekonstruowanego świata” (Jasieński 1974: 37), że jego słowa będą posiadały tę moc przeobrażania świata. Zdaje się jednak, że porzucenie poezji było pozorne - powieść wszak napisano językiem lirycznym, mocno zmetaforyzowanym; prozę ukształtowano na poetycką modłę (skondensowane przenośnie, rozpoetyzowana fraza). To właśnie język (a raczej języki różnych grup społecznych, religijnych, odmiennych stronnictw politycznych czy najprościej - etnosów) staje się najwyrazistszym bohaterem utworu.

Jasieński był pisarzem-polemistą, spierał się sam ze sobą — zarówno jego utwory literackie, jak i teksty programowe są wypowiedziami krytycznymi względem futuryzmu: czas futuryzmu minął, nurt ten okazał się efemeryczny i anachroniczny, a jego zakwestionowanie posiada u autora znamiona unicestwienia. Owa negacja to tylko skrajna forma awangardowej rebelii, istotny element paradygmatu:

Właściwy poecie estetyczny rytm negacji i kreacji - negacji odziedziczonych społecznych i estetycznych wartości i praktyk, oraz kreacji nowych form ekspresji i działania — jest postrzegany jako model indywidualnych i zbiorowych wysiłków, ku stworzeniu nowego społeczeństwa. (Russell 2001: 168)

Podkreślając idealizm i utopizm awangardowych poczynań, Russell zauważa ponadto:

podwójne poddaństwo [...] awangardy [...] wobec anarchistycznych i komunistycznych flag ujawnia także inherentne napięcia wszystkich tych wysiłków, aby stworzyć sztukę, która przyczyniłaby się - jeśli nie spowodowałaby go bezpośrednio — do osobistego i zbiorowego wyzwolenia. (Russell 2001: 166)

Awangardowa polemika totalna (Balcerzan 1974: 234) zmierzała do ostrych, skrajnych sądów, w tym także do sądu nad futuryzmem w momencie, gdy ruch ten miał już kilka lat, utracił atrybut nowości, będący fetyszem futurystów. Badacz stwierdza: „Istnieje wiele sposobów likwidacji futuryzmu. Wszystkie one jednak, zgodnie z dotychczasową tradycją polemiczną tego kierunku, powinny dawać okazję do krytyki — właśnie — likwidatorskiej. Żadnych półśrodków" (Jasieński 1974: 235). Półśrodków nie stosował autor manifestów futurystycznych, który w różnych formach ogłaszał koniec futuryzmu. Gdy Jasieński w 1923 roku w 6 numerze "Zwrotnicy” dokonywał bilansu polskiego futuryzmu, pojmował ten ruch jako organizowanie świadomości społecznej i artystycznej.

Zarówno Nogi Izoldy Morgan, jak i Palę Paryż można zaliczyć w poczet tekstów rozrachunkowych nie tylko wobec rzeczywistości społecznej, ale też względem futuryzmu. Poeta deklarował już w 1923 roku: „Futuryzm jest formą świadomości zbiorowej, którą należy przezwyciężyć. Ja futurystą już nie jestem, podczas gdy wy wszyscy jesteście futurystami” 
(Jasieński 1972: 223). I deklaracją tą rozliczył się z futuryzacją życia: urbanizmem, pędem postępu technologicznego, rewoltą maszyn, radykalnie zmienioną rzeczywistością i utopią nowego społeczeństwa. Wszystkie te elementy znajdziemy w warstwie fabularnej powieści.

Awangarda w swojej rewolucyjności jest rezonatywna - decyduje się na radykalne, często desperackie gesty w nadziei, że nawet jeżeli nie wywołają natychmiastowej zmiany, to zdołają wyrzeźbić inną przyszłość, zaistnieją w niej, wybrzmią w dniu jutrzejszym. Wystarczy sam gest, który w teraźniejszości nie spowoduje zupełnie niczego, ale zagwarantować może potencjalne życie pośmiertne awangardy, jej widmowe istnienie, możliwość ujścia poza siebie, niedomknięcie. Potencjalność i r e z o n a t y w ność awangardowego gestu to niezbywalny element strategii awangardzisty - twórcy coraz to nowych prób, praktyk, pomyłek, chybionych aliansów czy urojeń, które odziedziczyliśmy wraz z obietnicą wolności zawartą w oswobodzonym z rygorów języku.

\section{Bibliografia}

Balcerzan Edward (1968), Styl i poetyka twórczości dwujezycznej Brunona Jasieńskiego: z zagadnień teorii przektadu, Ossolineum, Wrocław-Warszawa-Kraków.

- (1974), „Nogi Izoldy Morgan” Brunona Jasieńskiego [w:] Nowela, opowiadanie, gawęda: interpretacja matych form narracyjnych, red. Bartoszyński K., Jasińska-Wojtkowska M., Sawicki S., PWN, Warszawa.

Bujnicki Tadeusz (1984), Twórczość prozatorska Brunona Jasieńskiego [w:] tegoż, Bunt żywiotów i logika dziejów. W kręgu idei polskiej lewicy, Wydawnictwo Śląsk, Katowice.

- (1993), Bruno Jasieński [w:] Literatura polska w okresie międzywojennym, red. Maciejewska I., Trznadel J., Pokrasenowa M., t. 3., Obraz literatury polskiej XIX i XX wieku, Wydawnictwo Literackie, Kraków.

Bürger Peter (2006), Teoria awangardy, przeł. J. Kita-Huber, red. nauk. Wilkoszewska K., Universitas, Kraków.

Czapliński Przemysław (1994), Obecna, nieusprawiedliwiona, „Teksty Drugie”, nr. 5-6.

Dziarnowska Janina (1978), Stowo o Brunonie Jasieńskim, Książka i Wiedza, Warszawa. Irzykowski Karol (1908), Dwie rewolucje, „Nasz Kraj”, z. 1.

Jasieński Bruno (1928), Solidarność z poetami proletariackimi, „Wiadomości Literackie”, nr 16. - (1956), Coś w rodzaju życiorysu, thum. G. Lasota, „Przegląd Kulturalny”, nr 17.

- (1972), Utwory poetyckie, manifesty, szkice, oprac. E. Balcerzan, Ossolineum, Wrocław.

- (1974), Pale Paryż, Czytelnik, Warszawa.

Jasieński Bruno, Stern Anatol (1987), Ziemia na lewo, Wydawnictwo Literackie, Kraków.

Jaworski Krzysztof (1995), Bruno Jasieński w sowieckim więzieniu. Aresztowanie, wyrok, śmierć, Wyższa Szkoła Pedagogiczna im. Jana Kochanowskiego, Kielce. 
- (2002), Przestrzeń fabularna i uksztattowanie jezyka narracji a idea polityczna. Na przyktadzie powieści Brunona Jasieńskiego „Palę Paryż”, „Studia Filologiczne AŚ, t. 17.

- (2003), Bruno Jasieński w Paryżu (1925-1929), Wydawnictwo AŚ, Kielce.

- (2009), Dandys. Stowo o Brunonie Jasieńskim, Iskry, Warszawa.

Kato Ariko (2018), Nieznana wersja „Palę Paryż" [w:] Polonistyka na początku XXI wieku. Diagnozy. Koncepcje. Perspektywy, t. 1: Literatura polska i perspektywy nowej humanistyki, red. Cudak R., Pospiszyl K., Tambor J., Wydawnictwo UŚ, Katowice.

Kitrasiewicz Piotr (2005), Morand-Jasieński. Pojedynek na miasta [w:] Jasieński B., Palę Paryż, Biblioteka Analiz, Warszawa.

Kolesnikoff Nina (1982), Bruno Jasieński. His Evolution from Futurism to Socialist Realism, Wilfrid Laurier UP, Waterloo, Ontario.

Lee Stephen Richard (1982), Trudne przymierze. Polska awangarda poetycka w kregu idei lewicy 1918-1939, PIW, Warszawa.

Lipatow Aleksander W. (1992), Awangarda: pokusa poezji i utopia wtadzy, „Teksty Drugie”, nr. $1-2$.

Lubelski Karol (1973), Anarchia i dyscyplina. O polskich powieściach Brunona Jasieńskiego, „Rocznik Komisji Historycznoliterackiej” XI, PAN, Wrocław.

Łobodowski Józef (1932), Literatura proletariacka, „Kurier Lubelski”, nr 86.

Majerski Paweł (2001), Odmiany awangardy, Wydawnictwo EGO (Stowarzyszenie Pisarzy Polskich Oddział w Katowicach), Katowice.

Mitzner Piotr (1993), Śmierć futurysty, „Karta”, nr 11.

Morand Paul (1928), Palę Moskwę [w:] tegoż, Swawolna Europa, Rój, Warszawa.

Morawski Stefan (1978), Awangarda i postawy zaangażowane, „Biuletyn Rady Artystycznej Związki Polskich Artystów Plastyków”, nr 3 (132).

Olsen Bjørnar (2013), W obronie rzeczy. Archeologia i ontologia przedmiotów, tłum. B. Shallcross, IBL PAN, Warszawa.

Peiper Tadeusz (1930), Gdynia. Polskie miasto portowe, „Tygodnik Ilustrowany” 1930, nr 6.

Rawiński Marian (1971), Wobec mitu zagrożenia Zachodu (O „Pale Paryż” Brunona Jasieńskiego) [w:] O prozie polskiej XX wieku. Materiaty konferencji ogólnopolskiej w Toruniu, listopad 1968, red. Hutnikiewicz A., Zaworska H., Zakład Narodowy im. Ossolińskich, Wrocław.

Roberts John (2010), Revolutionary Pathos, Negation, and the Suspensive Avant-Garde, „New Literary History", nr 41.

Russell Charles (2001), Konflikt między awangardowa wyobraźniqa i praxis, tłum. J. Płuciennik, „Teksty Drugie”, nr 5.

Segovia Jorge (1978), Awangarda jako projekcja rewolucji, tłum. K. Rodowska, „Literatura na Świecie”, nr 2.

Sers Phillippe (2010), The Radical Avant-Garde and the Contemporary Avant-Garde, „New Literary History", nr 41.

Stern Anatol (1969), Bruno Jasieński, Wiedza Powszechna, Warszawa.

Stępień Marian (1974), Bruno Jasieński, PWN, Warszawa-Kraków.

Szymański Jerzy [A. Stawar] (1929), „Palę Paryż”, „Miesięcznik Literacki”, nr 1.

Wójtowicz Aleksander (2010), Modernizacja i jej cień. O prozie pierwszej Awangardy [w:] Dwudziestolecie 1918-1939. Odkrycia. Fascynacje. Zaprzeczenia, red. Kowalczyk A.S., Wójcik T., Zieniewicz A., Elipsa, Warszawa. 